\title{
Fermentation of green alga sea-lettuce (Ulva sp) and metabolism of its sulphate by human colonic microbiota in a semi-continuous culture system
}

\author{
M Durand ${ }^{1}, \mathrm{P}$ Beaumatin ${ }^{1 *}$, B Bulman ${ }^{1}$, A Bernalier ${ }^{1}$, \\ JP Grivet $^{2}$, M Serezat ${ }^{1}$, G Gramet $^{1}$, M Lahaye $^{3}$ \\ ${ }^{I}$ Laboratoire de nutrition et sécurité alimentaire, Inra-CRJ, 78352 Jouy-en-Josas cedex; \\ ${ }^{2}$ Centre de biophysique moléculaire, CNRS et université d'Orléans, \\ IA, avenue de la Recherche, 45071 Orléans cedex 02; \\ ${ }^{3}$ Laboratoire de biochimie et technologie des glucides, Inra, BP 527, \\ 44026 Nantes cedex 03, France
}

(Received 17 October 1996; accepted 28 January 1997)

\begin{abstract}
Summary - The green alga, sea-lettuce ( Ulva sp), could be considered as a new source of dietary fibre. Ulva, however, contains high levels of sulphate, part of which is chemically bound in soluble polymers (ulvan). The purpose of this study was to assess the fermentation characteristics and sulphate metabolism of $U l v a$ and ulvan by human faecal bacteria fermentation system using a semi-continuous fermenter. Ulva and ulvan were poorly fermented, even after adaptation of the microbiota. Only $16.6 \%$ and $8.9 \%$ of $U l v a$ and ulvan organic matter, respectively, were recovered as short chain fatty acids. Nevertheless, $40 \%$ of the sulphate in Ulva was dissimilated to sulphide by sulphate-reducing bacteria. Supplementation of Ulva with more fermentable polysaccharides, such as algal xylan and resistant starch, though decreasing the ammonia production originating from Ulva protein degradation, did not significantly reduce the sulphide levels. It is postulated that unless crude Ulva is desulphated, its daily consumption at a level of $20 \mathrm{~g}$ of dry product could stimulate colonic microbial sulphate reduction, which may have detrimental effects for the host.
\end{abstract}

in vitro fermentation / $\mathrm{Ulva} /$ seaweed / colonic bacteria / sulphate reduction

Résumé - Étude en culture semi-continue de la fermentation de l'algue verte, laitue de mer (Ulva sp), et du métabolisme de ses sulfates par les microorganismes du côlon humain. L'algue verte, laitue de mer (Ulva sp), peut être considérée comme une nouvelle source de fibre alimentaire. Cependant, Ulva contient une teneur élevée en sulfates dont une partie est liée chimiquement à un ensemble de polymères solubles (ulvane). L'objet de cette étude a été d'étudier les caractéristiques fermentaires

* Correspondence and reprints

Tel: (33) 01346527 10; fax: (33) 0134652311. 
et le métabolisme du sulfate d'Ulva et d'ulvane en utilisant un système de fermentation semi-continu. Ulva et ulvane se sont montrés peu fermentescibles, même après adaptation de la microflore. Seuls $16,6 \%$ de la matière organique d'Ulva et $8,9 \%$ de celle d'ulvane ont été retrouvés sous forme d'acides gras à chaîne courte. Néanmoins, $40 \%$ des sulfates contenus dans Ulva ont été transformés en sulfure par les bactéries sulfatoréductrices. La supplémentation d'Ulva par des glucides plus fermentescibles tels que du xylane d'algue et de l'amidon résistant, bien que diminuant la production d'ammoniac due à la dégradation des protéines d'Ulva, n'a pas limité significativement la formation de sulfure. En conclusion, la consommation journalière de $20 \mathrm{~g}$ d'Ulva brute sèche, pourrait accroître la sulfatoréduction par la flore colique, ce qui pourrait avoir des conséquences défavorables pour l'hôte, à moins que ce produit ne soit préalablement désulfaté.

fermentation in vitro / Ulva / algue / flore colique / sulfatoréduction

\section{INTRODUCTION}

There is considerable evidence to support the view that fermentation of dietary fibres by anaerobic bacteria in the human colon contributes to the prevention of colonic diseases. Short chain fatty acids (SCFA), which are the principal end products of fermentation, have a variety of recognized physiological and clinical properties (Cummings, 1995). However, wide ranges of fermentability exist among different types of dietary fibres, and the action of an individual fibre depends on the extent of its breakdown, as well as on the pattern of its fermentation end products. For example, beneficial effects such as increase in stool output, dilution of colonic contents and production of distal colonic SCFAs are mainly associated with a low extent, or a slow rate of fermentation (Edwards, 1995). In this respect, the green alga, sea-lettuce (Ulva $\mathrm{sp}$ ), could be considered as a new interesting source of dietary fibre. This organism contains about $30 \%$ total dietary fibre of which $16.5 \%$ are soluble polysaccharides (Lahaye, 1991). Recent investigation has shown that Ulva and its soluble fibres, referred to as ulvan, were poorly fermented in vitro in batch culture with faecal bacteria (BobinDubigeon et al, 1996). Their particular chemical structures were suggested to explain this resistance to fermentation. How- ever, such short-term studies do not take into account the potential capacity of intestinal bacterial communities to adapt to break down the polysaccharides (Edwards, 1995). It has been shown in rat experiments that short ( 1 week) or longer-term adaptations (up to 12 weeks) were necessary to achieve the greatest digestibility or rate of fermentation of specific fibres such as gums (Walter et al, 1986; Tulung et al, 1987; Brunsgaard et al, 1995) or fibres from canned peas (Monsma and Marlett, 1996). In humans, when gum arabic was included in the diet for 18 days, the proportion of the faecal flora able to degrade this substrate progressively rose from 6.5 to more than $50 \%$. After the fibre was withdrawn from the diet, the proportion of gum arabic fermenting bacteria returned to the level present before ingestion (Wyatt et al, 1986). More recently, the necessity of adaptation of human subjects to xanthan gum, for their faecal microflora to achieve maximum hydrogen and SCFA production, was also demonstrated (Daly et al, 1993). Therefore, longer-term studies appear necessary to investigate whether adaptation of the flora occurs with this type of seaweed.

Another concern regarding Ulva is its high sulphate content, which can reach $17 \%$ of its dry matter (Bobin-Dubigeon et al, 1996). Part of this sulphate is chemically bound as in ulvan, which is a sulphated glu- 
curonorhamnoglycan, constituting between 12 and $15 \%$ of the algal dry matter (Michel and Macfarlane, 1996), and containing about $14 \%$ sulphate (Ray and Lahaye, 1995). This attribute could have significant consequences on microbial metabolism in the colon and potential health implications. The supply of free sulphate to the colon resulting either from a high sulphate intake, eg, $>5 \mathrm{mmol} / \mathrm{d}$ (Florin et al, 1991) or from the in situ microbial degradation of sulphated polymers (Gibson et al, 1988a, 1991) may stimulate the growth and activity of sulphate-reducing bacteria (SRB) (Christl et al, 1992). These organisms reduce sulphate to sulphide. When sulphate is abundant, this reaction can represent an important route of hydrogen $\left(\mathrm{H}_{2}\right)$ utilization in situ in the colon and may interact with other microbial pathways of $\mathrm{H}_{2}$ disposal, namely methanogenesis and reductive acetogenesis (acetate formation from $\mathrm{CO}_{2}$ reduction by $\mathrm{H}_{2}$ ) (Durand et al, 1995). In addition, hydrogen sulphide is toxic towards mammalian cells and it has been suggested that sulphide is a possible cofactor in the initiation and/or maintenance of the inflammatory bowel disease, ulcerative colitis (Gibson et al, 1991; Roediger et al, 1993). Consequently, knowledge of the fate of the sulphate associated with sealettuce is important to predict the potential health implications following its long-term consumption.

The purpose of the present study was to assess the effect of adaptation on the fermentation characteristics of Ulva and ulvan by human faecal bacteria, using a semi-continuous fermentation system. Emphasis was placed on the effect of these products on sulphate metabolism, and in order to ascertain more precisely the activities of SRB, the putatively specific inhibitor of sulphate reduction, sodium molybdate, was used. We also attempted to clarify if previous adaptation of the microflora to Ulva would affect its reductive acetogenic and methanogenic activities.

\section{MATERIALS AND METHODS}

\section{Materials}

Ulva sp, produced by Algues de Bretagne (France) as Laitue de mer was ground to pass through a $3 \mathrm{~mm}$ screen. It contained $90.4 \%$ dry matter (DM) and (\% DM): minerals, 19.7; total nitrogen, 4.9; sulphate, 11.6. Crude ulvan was provided by CEVA (Pleubian, France) and further processed by precipitation by Inra (Nantes, France). It contained (\% DM): minerals, 20.8; sulphate, 15.8. The red seaweed Palmaria palmata was also processed by CEVA in order to obtain a carbohydrate enriched product $(70 \%$ DM), mostly composed of xylan, and referred to in this paper as algal xylan. It contained $93.3 \%$ DM and (\% DM): minerals, 22.8; sulphate, 11.7. Sulphate was formed from sulphuric acid added during processing. The sulphate determinations on the above products were performed by Inra, Nantes (Lahaye and Axelos, 1993). Resistant starch was provided by Inra (Nantes), and consisted of retrograded high amylose maize starch (Faisant et al, 1993).

\section{Fermentation system}

The semi-continuous culture system used in this experiment was adapted from the 'Rusitec' designed by Czerkawski and Breckenridge (1977) for rumen fermentation studies, consisting of four independent $1 \mathrm{~L}$ capacity vessels. Fresh faecal samples were collected from two female subjects referenced as subjects $A$ and $B$. Methane was never detected in the exhaled breath of subject $A$, whereas subject $B$ was a methane excretor, but only exhaled moderate levels of methane (about $20 \mathrm{ppm}$ ). Freshly voided faeces were stored under anaerobic conditions and processed within $48 \mathrm{~h}$. All handling procedures were done under anaerobic conditions (under a gas phase of $100 \% \mathrm{~N}_{2}$ ).

For each vessel, $100 \mathrm{~g}$ faeces were homogenized in $500 \mathrm{~mL} \mathrm{CO}_{2}$-saturated mineral solution similar to that described by Michel et al (1996), except for $\mathrm{Na}_{2} \mathrm{SO}_{4}$, which was reduced by $50 \%$ $(0.05 \mathrm{~g} / \mathrm{L})$. The faecal slurries were then strained through four layers of surgical gauze, and the strained fluid was introduced into the fermentation vessels. The solid residues were placed into nylon bags $(160 \times 80 \mathrm{~mm}, 150 \mu \mathrm{m}$ pore size $)$ together with $5 \mathrm{~g}$ cut pre-fermented straw. This 
bag was introduced into the vessel and remained there throughout the experiment in order to permit bacterial attachment. The volume in the vessel was then adjusted to $1 \mathrm{~L}$ with a nutritive basal medium. This contained the mineral solution described above, together with a mixture of organic compounds (Sigma, France) $(\mathrm{g} / \mathrm{L})$ : porcin gastric mucin, 2; pancreatin, 1 ; casein, 2; cysteine, 0.2 ; haemin, 0.01 ; peptone, 0.01 ; bile salts ( $50 \%$ sodium cholate), 0.05 ; urea, 0.18 ; xylan, 0.5 ; pectin, 0.5 ; amylopectin, 0.5 ; arabinogalactan, 0.5 ; lintner starch, 0.5 and vitamins ( $\mathrm{mg} / \mathrm{L}$ ): riboflavin, 0.5 ; biotin, 0.012 ; cyanocobalamine, 0.005 ; folic acid, 0.012 ; nicotinic acid, pyridoxine $\mathrm{HCl}$, thiamine $\mathrm{HCL}$ and pantothenate, $1 \mathrm{mg} / \mathrm{L}$ each.

Each vessel was infused with the basal medium (BM) at an approximate rate of $1 \mathrm{~L} / \mathrm{d}$. When Ulva was tested, nylon bags containing $15 \mathrm{~g} \mathrm{Ulva}$ were introduced into the vessels and removed $48 \mathrm{~h}$ later. The bags were washed with the mineral solution, and the washings were put back into the fermentation vessels. When algal xylan and resistant starch were used to supplement Ulva, they were injected into the vessel twice per day as a suspension in distilled water $(3 \mathrm{~g} / 20 \mathrm{~mL}$ and $2.5 \mathrm{~g} / 20 \mathrm{~mL}$ for algal xylan and resistant starch, respectively). When ulvan was tested, the substrate was solubilized in distilled water $(2.5 \mathrm{~g} / 20 \mathrm{~mL})$ and injected twice daily into the fermenters. Sodium molybdate and 2-bromo ethanesulfonic acid, when necessary, were introduced into the basal medium and infused continuously.

\section{Experiments}

Four experiments (studies 1 to 4) were conducted to study Ulva fermentation and sulphate metabolism and one (study 5) to study ulvan fermentation and sulphate metabolism. The inoculum from subject $\mathrm{A}$ (non-methanogenic) was used in studies 1, 2 and 5 and the inoculum from subject B was used in studies 3 and 4 . The experiments were conducted according to the following experimental design:

Study 1: fermentation of the basal culture medium without (one vessel) or with addition of Ulva (one vessel) was followed for 12 days.

Study 2: the aim in this experiment was to concentrate on sulphate metabolism and its effect on reductive acetogenesis. Two vessels were first adapted to Ulva for 10 days, then one of the vessels received sodium molybdate $(20 \mathrm{mM})$, and the experiment was run for a further 10 days.

Study 3: Ulva fermentation and sulphate metabolism were studied for 7 days in the presence (two vessels) or absence (two vessels) of the methanogenesis inhibitor 2-bromoethanesulfonic acid (BES) $(20 \mathrm{mM})$, since the inoculum $B$ was putatively methanogenic. The former vessels (Ulva alone) also served as a control for study 4.

Study 4: the effect of Ulva supplementation with algal xylan (two vessels) and resistant starch (two vessels) on the pattern of fermentation and sulphate metabolism was investigated for 7 days. One vessel of each group received sodium molybdate $(15 \mathrm{mM})$ from the beginning of the incubation.

Study 5: fermentation and sulphate metabolism in the basal culture medium alone (two vessels) or supplemented with ulvan (two vessels) were studied for 7 days. One vessel from each group received sodium molybdate as indicated above.

\section{Bacteriological and chemical analyses}

\section{Bacterial enumerations}

Total anaerobes, methanogenic archaea, sulphatereducing and acetogenic bacteria were enumerated in experiments 2 and 3 in the original faecal samples (donors $\mathrm{A}$ and $\mathrm{B}$, respectively) and in the fermentation vessels at the end of the incubations, following the methods described by Doré et al (1995a) and Bernalier et al (1996a).

\section{Chemical analyses on spent culture media}

Effluents from the fermenters were collected daily. SCFA were analysed by capillary GC after conversion to tertiary butyldimethylsilyl derivates (Richardson et al, 1989). Ammonia nitrogen $\left(\mathrm{NH}_{3}-\mathrm{N}\right)$ and protein nitrogen (protein-N) were determined on three consecutive days at the end of studies 1,2 and $4 . \mathrm{NH}_{3}-\mathrm{N}$ was measured by titration after displacement by magnesium oxide $(0.1 \mathrm{M})$, and protein- $\mathrm{N}$ was precipitated by trichloracetic acid (10\% final concentration), centrifuged and determined by the Kjeldahl method. Sulphate was determined at intervals in 
all experiments except for study 1 . Sulphate was assayed by turbidimetry after treatment with TCA and in the presence of $\mathrm{BaCl}_{2}$ and polyethylene glycol (Bo Sörbo, 1987).

\section{Analyses on the liquid phase of the fermenters}

Samples were taken from the fermenters every morning just before the change of feed bag of Ulva, or just before the injection of ulvan. On these samples, $\mathrm{pH}$ was recorded daily and sulphides were determined at intervals in studies 2 and 3 and daily in studies 4 and 5 . Sulphides were assayed by the colorimetric method of Cline (1969) after precipitation of sulphides in $10 \%$ (wt/vol) zinc acetate solution (Gibson et al, 1988b). In addition, on two different days after adaptation, $\mathrm{pH}$ was recorded at different times up to $7 \mathrm{~h}$ after feeding the substrates.

\section{Collection and analysis of gases}

Fermentation gases corresponding to each vessel were collected daily in a glass cylinder and volume was measured by liquid displacement. Except for studies 1 and 2, the gas was previously bubbled through zinc acetate (10\% wt/vol) to trap any gaseous sulphide. Samples of gas were then analysed for $\mathrm{H}_{2}, \mathrm{CH}_{4}$ and $\mathrm{CO}_{2}$ by $\mathrm{GC}$ (De Graeve et al, 1994) and trapped sulphide was determined as above.

\section{Measurement of reductive acetogenic activity by ${ }^{13} \mathrm{C} N M R$}

At the end of studies 2 and 3 the microbiotas from each vessel were collected by centrifugation $\left(27000 \mathrm{~g}\right.$ for $30 \mathrm{~min}$ at $4^{\circ} \mathrm{C}$ ) under $\mathrm{N}_{2}$ gas phase. Aliquots were incubated for $16 \mathrm{~h}$ in $120 \mathrm{~mL}$ penicillin flasks in the presence of $\mathrm{NaH}^{13} \mathrm{CO}_{3}$ with $\mathrm{H}_{2}$ as gas phase. The effect of sulphate addition was assessed by adding $7 \mathrm{mM} \mathrm{Na} \mathrm{SO}_{4}$ to half of the flasks. Incorporation of ${ }^{13} \mathrm{CO}_{2}$ into acetate was measured by ${ }^{13} \mathrm{C}-\mathrm{NMR}$ as described by De Graeve et al (1994).

\section{Statistical analysis}

Experimental values were compared by ANOVA and with the Newman-Keuls multiple range test (STATITCF software; ITCF, Paris).

\section{RESULTS}

\section{Bacterial enumeration}

In the original faeces, the number of total anaerobes and of reductive acetogens was lower with donor B while those of sulphatereducing bacteria (SRB) were similar for both individuals (table I). In agreement with breath tests, methanogens were not detectable in faeces from donor $\mathrm{A}$, and their numbers were just significant in those from donor B.

In the fermentation vessels, despite the ten-fold dilution of faeces, the number of total anaerobes, SRB and acetogenic bacteria remained close to that of the original faeces, with both inocula. However, the number of methanogens from donor B was greatly decreased compared to the original faeces. Addition of sodium molybdate lowered the SRB population and that of BES practically eliminated the methanogens (table I).

\section{End products of fermentation}

Results concerning the production of SCFA in the presence of Ulva that were obtained in studies 1 and 2 with inoculum A did not show any difference with those obtained in study 3 with inoculum B. The mean production after 5 days adaptation was $70.5 \pm 2.1$ and $70.9 \pm 2.0 \mathrm{mmol} /$ day for donors A and B, respectively. Therefore, data obtained with both inocula were pooled.

\section{Effect of adaptation on SCFA production}

Daily production of SCFA during 12 days adaptation to the basal medium was steady from day 4 to day 9 , before decreasing by $10 \%$ (fig 1). During the same period, Ulva addition resulted in a gradual rise in SCFA, which levelled off after day 5 of the incubation, showing that about 5 days were required for full adaptation of the flora to 
Table I. Enumeration of total viable anaerobes and $\mathrm{H}_{2}$-utilizing microorganisms in original faeces and in fermenter contents at the end of incubation.

\begin{tabular}{|c|c|c|c|}
\hline & \multirow[t]{2}{*}{$\begin{array}{c}\text { Original counts } \\
\log N / g \text { faeces (wet) }\end{array}$} & \multicolumn{2}{|c|}{$\begin{array}{c}\text { Final counts } \\
\log N / m L \text { vessel content }\end{array}$} \\
\hline & & Ulva & $\mathrm{Ulva}+\mathrm{Mo}^{\mathrm{a}}$ \\
\hline \multicolumn{4}{|l|}{ Inoculum A } \\
\hline \multicolumn{4}{|l|}{ Experiment 2} \\
\hline Total anaerobes & 11.6 & 9.4 & 10.1 \\
\hline Sulphate reducing bacteria & 8.9 & 10.1 & 6.2 \\
\hline Acetogenic bacteria & 6.4 & 6.4 & 6.4 \\
\hline \multirow[t]{2}{*}{ Methanogenic archaea } & $<2.0$ & $<2.0$ & $<2.0$ \\
\hline & & Ulva & $U l v a+B E S^{\mathrm{b}}$ \\
\hline \multicolumn{4}{|l|}{ Inoculum B } \\
\hline \multicolumn{4}{|l|}{ Experiment 3} \\
\hline Total anaerobes & 10.6 & 10.7 & 10.2 \\
\hline Sulphate reducing bacteria & 8.7 & 8.9 & 8.2 \\
\hline Acetogenic bacteria & 4.9 & 4.4 & 4.8 \\
\hline Methanogenic archaea & 7.5 & 4.4 & $<2.0$ \\
\hline
\end{tabular}

${ }^{a}$ Mo: sodium molybdate; ${ }^{b}$ BES: 2-bromoethane-sulfonic acid.

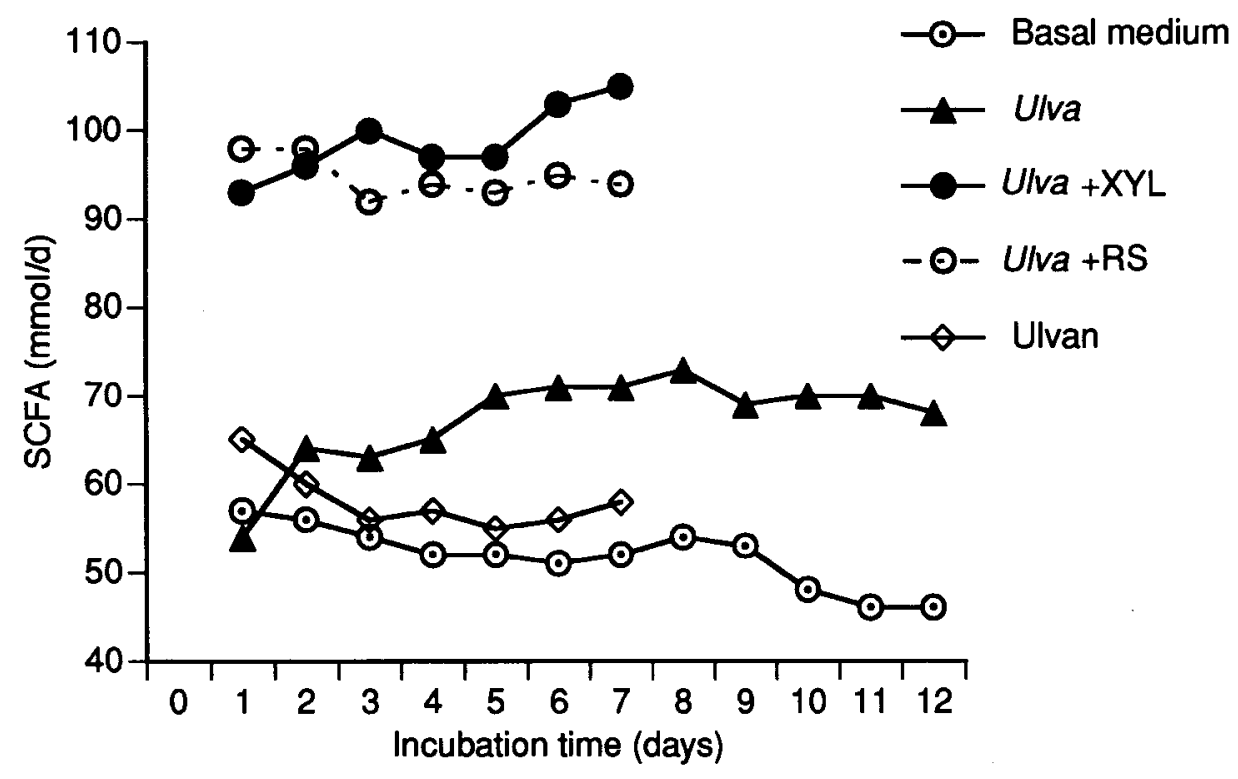

Fig 1. Influence of adaptation on daily SCFA production with the basal medium, Ulva, Ulva supplemented with algal xylan (Ulva $+\mathrm{XYL}$ ), Ulva supplemented with resistant starch (Ulva+RS) and ulvan. 
Ulva (fig 1). Consequently, the durations of studies 3-5 were reduced to 7 days.

Supplementation of Ulva by algal xylan (XYL) and resistant starch (RS) greatly increased total SCFA production from the first day of incubation. Then, it remained nearly constant with resistant starch and increased slightly with xylan (fig 1). When ulvan was the substrate, SCFA production first decreased by $15 \%$ from day 1 to day 3 and then stabilized at a level only slightly higher than that of the basal medium alone (fig 1).

\section{Balance of end products}

The balance of end products was calculated as the mean of the production on days 5,6 and 7 (table II). Compared to the basal medium, Ulva addition significantly increased all SCFAs and had only a small effect on their molar proportion (table II): there was a small decrease in acetate ratios and a slight but significant rise in valerate and the branched chain fatty acids (BCFA) isobutyrate and isovalerate. Calculation of SCFA production owing to Ulva alone (Ulva vessels minus basal medium vessels) showed that (weight by weight), $9 \%$ of the crude product or $16.6 \%$ of its organic matter were recovered as SCFA.

The increase in SCFA effected by carbohydrate supplementation was significantly more marked with algal xylan than with resistant starch. Compared to Ulva alone, algal xylan elevated the molar proportion of propionate and lowered that of butyrate, whereas resistant starch slightly increased acetate. Both carbohydrates decreased the relative proportions of isovalerate and valerate (table II). In addition, resistant starch resulted in the formation of some longer chain fatty acids such as caproic and heptanoic acids ( 1.7 and $0.7 \mathrm{mmol} /$ day, respectively). SCFA formed from algal xylan and resistant starch alone (carbohydrate supplemented vessels minus Ulva vessels) amounted to (weight by weight) 34 and $37 \%$ of the crude products, and to 47.9 and $41.4 \%$ of their organic matters, respectively.

Table II. Daily end products of fermentation from the basal medium (BM) and after addition of Ulva, Ulva + algal xylan (+ XYL), Ulva + resistant starch (+ RS) and ulvan, A 20.

\begin{tabular}{lcccccc}
\hline & $B M$ & Ulva & $+X Y L$ & $+R S$ & Ulvan & Pooled SE \\
\hline Short-chain fatty acids & $51.6^{\mathrm{e}}$ & $70.4^{\mathrm{c}}$ & $101.4^{\mathrm{a}}$ & $92.6^{\mathrm{b}}$ & $56.4^{\mathrm{d}}$ & 2.1 \\
Total (mmol/day) & & & & & & \\
Molar proportion (\%) & & & & & & \\
Acetic & $61.0^{\mathrm{a}}$ & $57.9^{\mathrm{b}}$ & $58.1^{\mathrm{b}}$ & $60.4^{\mathrm{a}}$ & $62.0^{\mathrm{a}}$ & 0.8 \\
Propionic & $20.5^{\mathrm{b}}$ & $20.9^{\mathrm{b}}$ & $26.3^{\mathrm{a}}$ & $19.9^{\mathrm{b}}$ & $19.1^{\mathrm{b}}$ & 0.8 \\
Butyric & $10.7^{\mathrm{a}}$ & $11.5^{\mathrm{a}}$ & $9.0^{\mathrm{b}}$ & $11.3^{\mathrm{a}}$ & $10.9^{\mathrm{a}}$ & 0.5 \\
Isobutyric & $2.1^{\mathrm{b}}$ & $2.8^{\mathrm{a}}$ & $2.0^{\mathrm{b}}$ & $2.6^{\mathrm{a}}$ & $2.2^{\mathrm{b}}$ & 0.1 \\
Valeric & $3.9^{\mathrm{b}}$ & $4.5^{\mathrm{a}}$ & $3.0^{\mathrm{c}}$ & $4.0^{\mathrm{b}}$ & $3.8^{\mathrm{b}}$ & 0.2 \\
Isovaleric & $1.9^{\mathrm{b}}$ & $2.5^{\mathrm{a}}$ & $1.5^{\mathrm{c}}$ & $1.9^{\mathrm{b}}$ & $1,9^{\mathrm{b}}$ & 0.2 \\
Carbon dioxide (mmol/day) & $8.2^{\mathrm{e}}$ & $17.5^{\mathrm{c}}$ & $28.0^{\mathrm{b}}$ & $32.4^{\mathrm{a}}$ & $12.4^{\mathrm{d}}$ & 2.3 \\
Ammonia-N (mg/day) & $412^{\mathrm{c}}$ & $563^{\mathrm{a}}$ & $500^{\mathrm{b}}$ & $487^{\mathrm{b}}$ & - & 29 \\
Protein-N (mg/day) & $133^{\mathrm{c}}$ & $175^{\mathrm{b}}$ & $276^{\mathrm{a}}$ & $294^{\mathrm{a}}$ & - & 13 \\
pH & $6.90^{\mathrm{a}}$ & $6.86^{\mathrm{b}}$ & $6.74^{\mathrm{c}}$ & $6.76^{\mathrm{c}}$ & $6.84^{\mathrm{b}}$ & 0.02 \\
\hline
\end{tabular}

Results are means of days $5,6,7$.

$n=6$ for BM, 12 for Ulva, 3 for Ulva, + XYL, + RS and ulvan.

a, b, c, d, e : means within a row, values with different superscripts were significantly different at $P<0.05$. 
Compared to the basal medium, the addition of ulvan increased slightly $(<10 \%)$, although significantly, total SCFA production, and this increase was entirely due to a rise in acetate (table II). The amount of SCFA produced from ulvan (ulvan vessel minus basal medium vessel) represented only $6.4 \%$ of crude ulvan and $8.9 \%$ of its organic matter.

Carbon dioxide $\left(\mathrm{CO}_{2}\right)$ was the main fermentation gas produced. Compared to the basal medium, addition of Ulva and its further supplementation with algal xylan or resistant starch greatly increased the volume of $\mathrm{CO}_{2}$ released (from about $200 \mathrm{~mL}$ up to $800 \mathrm{~mL} /$ day). Ulvan addition also resulted in a significant increase in $\mathrm{CO}_{2}(+34 \%)$ compared to the basal medium. Hydrogen was detected at very low levels except on the last two days of incubation in the presence of resistant starch (mean: $2.2 \mathrm{mmol} / \mathrm{day}$ ), and following sodium molybdate addition (see below). Only trace amounts of methane were detected in the vessels from studies 3 and 4, which were inoculated with faeces from donor $B$. Therefore, the addition of BES in study 3 had no effect at all on the fermentation end products from Ulva (results not shown).

Both protein- and ammonia-N output were increased by Ulva addition. Algal xylan and resistant starch supplementation of Ulva increased protein- $\mathrm{N}$ but decreased ammonia-N (table II).

The initial (before feeding) $\mathrm{pH}$ of the fermenters receiving the basal medium, Ulva alone and ulvan were not significantly different and remained near neutral (6.8-6.9) (table II). When both carbohydrates were added, the initial $\mathrm{pH}$ valves were significantly lower ( -0.1 unit). After feeding, the $\mathrm{pH}$ rose briefly with $U l v a$, decreased within $2 \mathrm{~h}$ with xylan and remained stable with resistant starch (fig 2).

\section{Sulphate metabolism and the effect of sodium molybdate}

\section{Sulphate metabolism in the absence of molybdate}

The basal medium contained very low levels of sulphate $(0.35 \mathrm{mmol} / \mathrm{L})$. Nevertheless, sulphides were detected in culture vessels at a higher concentration than that of sulphate, demonstrating that some sulphides must have originated from other sources.

Ulva feeding increased the daily sulphate input by $15 \mathrm{mmol}$. However, irrespective of the inoculum, sulphate recovery in the effluent was low, while sulphide concentrations in the vessels rose to about $6 \mathrm{mmol} / \mathrm{L}(6.0 \pm 0.6$ for inoculum $\mathrm{A}$, and $6.7 \pm 0.6$ for inoculum B). In table III, the results of both inocula were pooled.

Ulva supplementation with resistant starch did not change the sulphate input, whereas algal xylan added $6.8 \mathrm{mmol} / \mathrm{day}$. It can be observed from figure 3 that with resistant starch, sulphate disappeared from the culture effluents within the first 3 days of incubation, whereas with algal xylan, it increased up to day 3 , before declining. With both carbohydrates, sulphide concentrations in the vessels rose up to day 4 , and then remained almost constant ( 6 to $7 \mathrm{mmol} / \mathrm{L}$ ) (fig 3). Finally, on the last days of incubation, the sulphide concentrations were not significantly different for all vessels fed Ulva (table, III).

Some gaseous sulphide was produced from the vessels fed Ulva, but the amounts were low (mean values for the three last days: $0.56 \pm 0.05,0.95 \pm 0.10$ and $0.68 \pm$ $0.03 \mathrm{mmol} /$ day for Ulva alone, + RS and + XYL, respectively).

Ulvan addition supplied daily a total of $7.4 \mathrm{mmol}$ sulphate. Some sulphate was recovered in the culture effluents but sulphide concentrations in the fermenters remained similar to those of the basal medium (table III). 

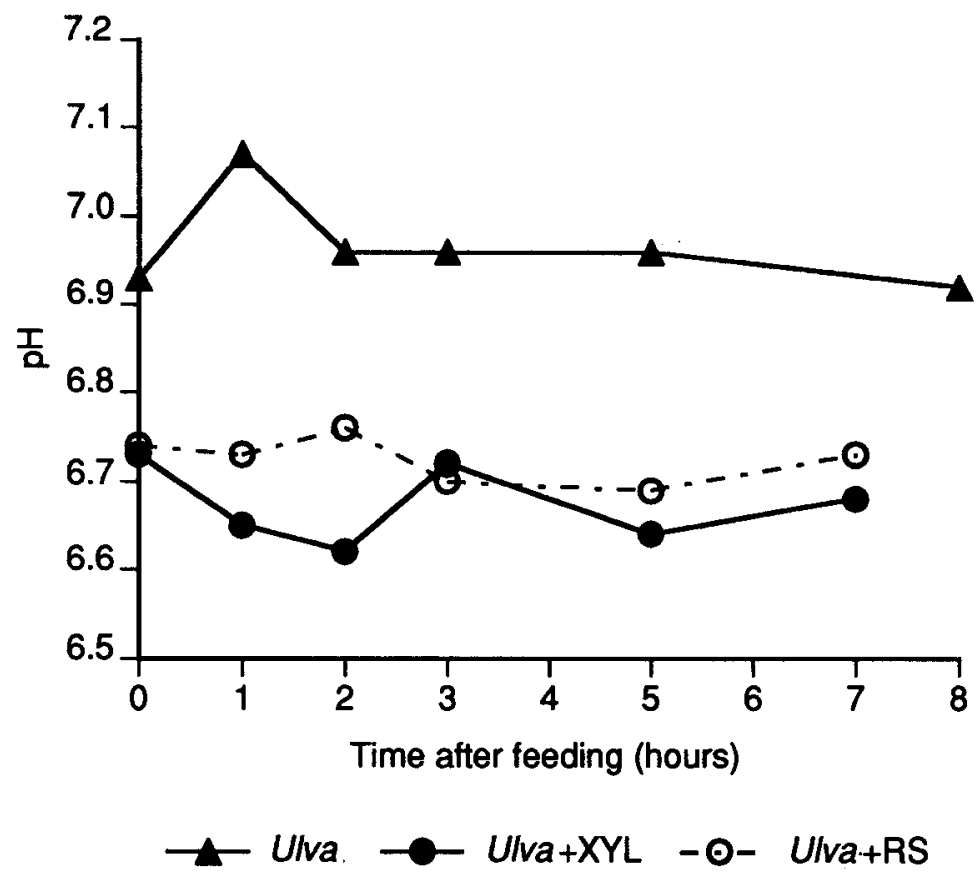

Fig 2. $\mathrm{pH}$ measurements in the fermenters after feeding Ulva, Ulva supplemented with algal xylan (Ulva $+\mathrm{XYL})$ and Ulva supplemented with resistant starch (Ulva + RS).

Table III. Recovery of sulphate in the effluent and sulphide concentration in the vessels in the presence and absence of sodium molybdate (Mo).

\begin{tabular}{lcccc}
\hline & \multicolumn{2}{c}{$\begin{array}{c}\text { Sulphate recovery } \\
\text { (mmol/day) }\end{array}$} & \multicolumn{2}{c}{$\begin{array}{c}\text { Sulphide concentration } \\
\text { (mmol/L) }\end{array}$} \\
& $-M o$ & $+M o$ & $-M o$ & $+M o$ \\
\hline Basal medium & $\mathrm{nd}^{\mathrm{d}}$ & $\mathrm{T}^{\mathrm{e}}$ & $1.6 \pm 0.1$ & $1.2 \pm 0.1$ \\
Ulva & $1.7 \pm 1.4$ & $8.1 \pm 0.3$ & $6.3 \pm 0.7$ & $1.4 \pm 0.1$ \\
Ulva $+\mathrm{XYL}^{\mathrm{b}}$ & $7.1 \pm 1.0$ & $10.3 \pm 0.7$ & $7.0 \pm 0.7$ & $2.0 \pm 0.3$ \\
Ulva $+\mathrm{RS}^{\mathrm{c}}$ & $\mathrm{T}^{\mathrm{e}}$ & $5.2 \pm 0.3$ & $6.3 \pm 0.1$ & $2.0 \pm 0.1$ \\
Ulvan & $2.0 \pm 0.2$ & $2.6 \pm 0.6$ & $1.5 \pm 0.2$ & $1.1 \pm 0.2$ \\
\hline
\end{tabular}

Results are means \pm standard errors of the three last days of experiments.

${ }^{a}$ Before feeding the substrates; ${ }^{b}$ XYL, algal xylan; ${ }^{c}$ RS, resistant starch; ${ }^{d}$ nd, not detectable; ${ }^{\text {e }}$ T, trace amounts $(<0.3 \mathrm{mmol})$. 

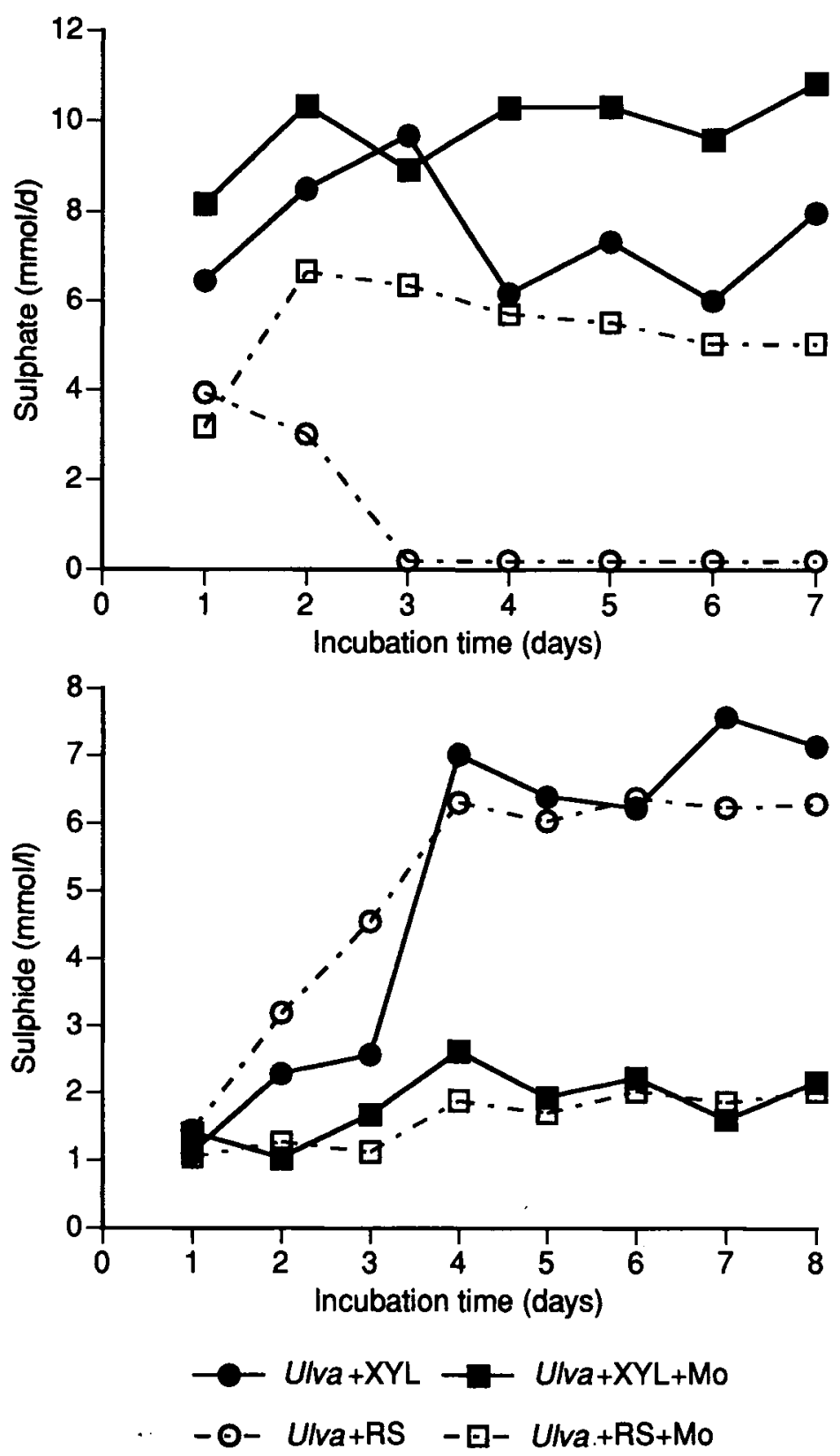

Fig 3. Influence of adaptation on daily sulphate output and sulphide concentrations in fermenters fed Ulva supplemented with algal xylan (Ulva + XYL) and Ulva supplemented with resistant starch $(U l v a+\mathrm{RS})$ in the presence and absence of sodium molybdate $(+\mathrm{Mo})$. 


\section{Effect of molybdate addition on sulphate metabolism}

With the basal medium and with ulvan, molybdate had only a slight depressing effect on sulphide concentrations $(-0.4 \mathrm{mmol} / \mathrm{L})$. Conversely, in all the vessels fed Ulva, molybdate significantly increased sulphate output and strongly decreased sulphide concentrations. However, the increase in sulphate output was less marked in the presence of algal xylan (fig 3, table III).

\section{Effect of molybdate addition on end products of fermentation}

Whatever the treatments, total SCFA production was decreased by molybdate. This was generally due to a reduction in acetate, except with xylan, where propionate was reduced by $30 \%$ (table IV). In all the vessels fed Ulva, molybdate addition resulted in production of formate and hydrogen (fig 4). With Ulva alone, these productions were low and transient, whereas they were more abundant and lasted longer with addition of carbohydrates, especially with resistant starch (fig 4).

\section{Reductive acetogenesis of the microflora adapted to $U l v a$}

Despite adaptation of the microflora to Ulva, which was rich in sulphate, synthesis of
${ }^{13} \mathrm{C}$-acetate from ${ }^{13} \mathrm{CO}_{2}$ was intense in the absence of added sulphate (table V). In both cases the ratio of double-labelled acetate to total labelled acetate represented about $40 \%$, and on average, the labelling was equally distributed among the methyl and carboxyl groups of acetate.

Adaptation of the microflora to molybdate (study 2) reduced both total acetate production by the culture and the proportion of labelled acetate in total acetate (table V).

Addition of sodium sulphate to the bath cultures reduced total acetate and the synthesis of acetate from ${ }^{13} \mathrm{CO}_{2}$ in study 2 but not in study 3 . Here, one of the vessels that showed a high ${ }^{13} \mathrm{CO}_{2}$ incorporation into acetate was not negatively affected by sulphate addition in contrast with the other two. This explains the particularly high values of standard errors (table V).

\section{DISCUSSION}

\section{Fermentation pattern}

In this study, we used continuous rather than batch cultures because we hypothesized that adaptation of the colonic bacteria to the seaweed $U l v a$ and its main soluble constituent ulvan was necessary to optimize their fermentation, since these substrates are not routinely part of the diet. The results we obtained on SCFA production from Ulva do not show strong adaptative effects (fig 1).

Table IV. Changes (+ or - ) of short chain fatty acid production induced by sodium molybdate (Mo) (mmol/day) (means $\pm \mathrm{SE}$ of d5, 6 and 7 after Mo addition).

\begin{tabular}{lccccc}
\hline & $B M$ & Ulva & $+X Y L$ & $+R S$ & Ulvan \\
\hline Total SCFA & $-8.9 \pm 1.9$ & $-5.7 \pm 1.7$ & $-9.5 \pm 3.7$ & $-16.6 \pm 2.2$ & $-4.9 \pm 1.7$ \\
Acetate & $-7.8 \pm 0.8$ & $-11.0 \pm 1.0$ & $\mathrm{nsc}^{\mathrm{a}}$ & $-16.1 \pm 2.2$ & $-6.1 \pm 1.0$ \\
Propionate & $\mathrm{nsc}^{\mathrm{a}}$ & $+3.6 \pm 1.5$ & $-8.6 \pm 1.1$ & $-3.5 \pm 1.5$ & $\mathrm{nsc}^{\mathrm{a}}$ \\
Butyrate & $\mathrm{nsc}^{\mathrm{a}}$ & $\mathrm{nsc}^{\mathrm{a}}$ & $+1.7 \pm 0.7$ & $+2.7 \pm 1.1$ & $+0.8 \pm 0.2$ \\
\hline
\end{tabular}

a nsc: no significant change. 
The first period of adaptation may have been due to enzyme induction, which is a comparatively rapid process (Salyers, 1985; Macfarlane et al, 1990). Then the number of bacterial species able to degrade Ulva may have slightly increased. This slight adaptation of the microflora to Ulva was not shown with ulvan. On the contrary, inhibitory effects on SCFA production seemed to occur from day 1 to day 3 of the incubation. This observation is consistent with the partial inhibitory effect of ulvan over cellulase activity that has been recently detected (Bobin-Dubigeon, 1996).
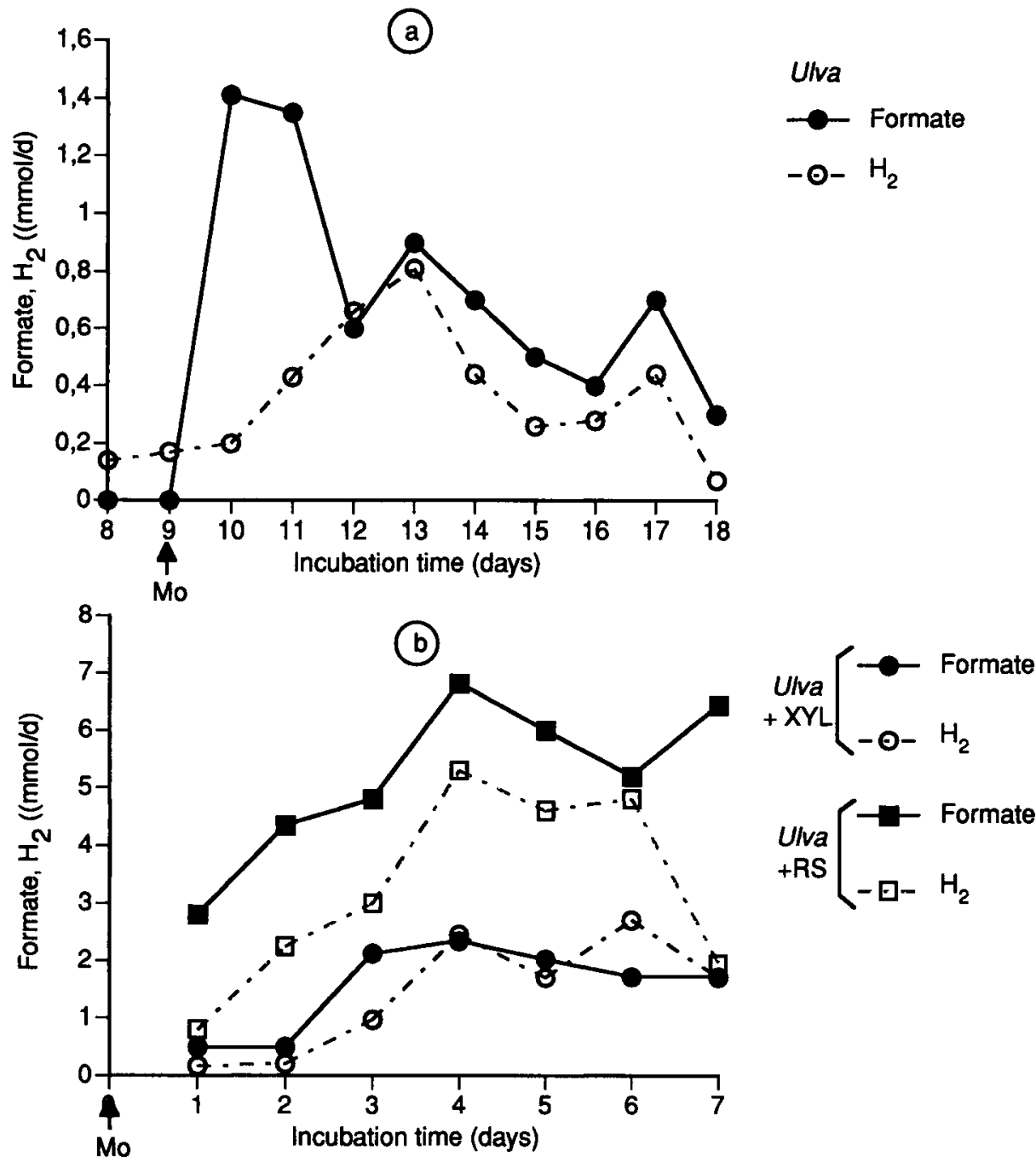

Fig 4. Effect of sodium molybdate on formate and hydrogen $\left(\mathrm{H}_{2}\right)$ production with $U l v a$, a and $\mathbf{b}$, Ulva supplemented with algal xylan (Ulva $+\mathrm{XYL})$ and Ulva supplemented with resistant starch (Ulva + RS). 
Table V. Total acetate and ${ }^{13} \mathrm{C}$-acetate formation from ${ }^{13} \mathrm{CO}_{2}$ in batch incubations of $U l v a$ adapted flora.

\begin{tabular}{|c|c|c|c|c|c|}
\hline \multirow[b]{2}{*}{ Acetate } & \multicolumn{3}{|c|}{ Inoculum $A$, study 2} & \multicolumn{2}{|c|}{ Inoculum B, study 3} \\
\hline & $-\mathrm{Mo}-\mathrm{SO}_{4}{ }^{2-}$ & $+\mathrm{Mo}-\mathrm{SO}_{4}{ }^{2-}$ & $-\mathrm{Mo}-\mathrm{SO}_{4}{ }^{2-}$ & $-\mathrm{SO}_{4}^{2-}$ & $+\mathrm{SO}_{4}^{2-}$ \\
\hline Total (mM) & $43.4 \pm 1.6$ & $21.2 \pm 0.6$ & $33.6 \pm 0.4$ & $39.9 \pm 2.5$ & $38.4 \pm 4.3$ \\
\hline Total labelled (mM) & $12.9 \pm 2.0$ & $4.1 \pm 1.0$ & $7.5 \pm 1.0$ & $14.7 \pm 2.8$ & $11.4 \pm 4.5$ \\
\hline \multicolumn{6}{|l|}{ Double labelled } \\
\hline$\%$ total labelled & $44.0 \pm 1.4$ & $42.5 \pm 1.9$ & $38.7 \pm 0.6$ & $43.5 \pm 3.0$ & $41.0 \pm 8.3$ \\
\hline
\end{tabular}

$+\mathrm{Mo}$, the flora had been previously incubated in the presence of sodium molybdate and $10 \mathrm{mM}$ sodium molybdate were added to the batch cultures. $+\mathrm{SO}_{4}^{2-}, 7 \mathrm{mM}$ sodium sulphate were added to the batch cultures.

Ulva was fermented to a very limited extent compared to algal xylan and resistant starch, which provided three times more SCFA per gramme of organic matter. In addition, the small amounts of SCFA formed from Ulva did not appear to originate from its soluble carbohydrates: ulvan. These data support the previous findings of BobinDubigeon et al (1996) who, using batch culture, showed that insoluble fibres contained in Ulva were more fermentable that the soluble ones (ulvan). This resistance was mainly attributed to the particular chemical structure (linkage and sequence of sugars) of these soluble polymers (Bobin-Dubigeon et al, 1996) and to the lack of the specific depolymerases in colonic microorganisms (Michel and Macfarlane, 1996).

Addition of Ulva to the basal medium increased the relative proportion of the BCFA, isobutyrate and isovalerate. Similar observations were made in batch cultures (Bobin-Dubigeon et al, 1996). These BCFA are generated almost exclusively from amino acid fermentation, especially from valine and leucine, and are therefore good markers of protein breakdown (Macfarlane and Cummings, 1991). From the results of production of SCFA from casein and bovine serum albumin obtained in batch-cultures, Mac- farlane et al (1992) assumed that approximately $30 \%$ by weight of the protein broken down is converted to SCFA and that BCFA constitute $20 \%$ of these SCFA. These data enabled us to estimate the protinaceous materials that were broken down during our incubations. The calculated values were $2.4 \mathrm{~g} /$ day for the basal medium alone and $2 \mathrm{~g} /$ day for Ulva alone. This would mean that all the proteinaeous materials of the basal medium and about half those of Ulva were degraded which is in line with the amount of ammonia produced. In vivo, it is not known whether and to what extent Ulva proteins are absorbed in the upper part of the intestine. Their contribution to the formation of SCFA or of ammonia in the large intestine cannot therefore be estimated.

Yields of SCFA obtained from the fermentation of algal xylan and resistant starch were relatively high (48 and $41 \%$ organic matter, respectively) and comparable with the figures given for cell wall polysaccharides (35-54\%) by Cummings (1995). These substrates provided energy for microbial growth as shown by the clear-cut increase in protein formation following their addition. We can estimate that 2.3 and $2.6 \mathrm{~g}$ microbial protein-N were produced by $100 \mathrm{~g}$ OM fermented for algal xylan and resistant starch, 
respectively. This corresponds approximately to an efficiency of microbial synthesis of $30 \%$ (weight by weight), a value that is comparable with that calculated by Cummings (1984), from excretion of faecal bacterial mass. The decrease in ammonia observed with these polysaccharides could result either from inhibition of amino acid deamination, or from a greater ammonia uptake for microbial protein synthesis. The latter was more likely under our conditions because the absolute levels of BCFA did not change with carbohydrate supplementation. Ammonia formation has a number of possible harmful health implications (Macfarlane and Cummings, 1991), therefore, if part of Ulva proteins reach the large intestine, supplementing this product with such polysaccharides should be beneficial for the host.

Algal xylan and resistant starch showed different fermentation patterns. Resistant starch (retrograded amylomaize starch) had a slow rate of fermentation, as shown by the stability of the $\mathrm{pH}$ after feeding. These characteristics were already observed when we compared the same resistant starch to lactulose (Doré et al, 1995b). Algal xylan fermented rapidly, induced a $\mathrm{pH}$ decrease shortly after feeding, and produced high proportions of propionic acid, thus corroborating previous observations of Lahaye et al (1993).

\section{Metabolism of sulphate from Ulva and possible interactions with methanogenesis and acetogenesis}

Our study clearly showed the importance of sulphide production in all the vessels fed Ulva. About $40 \%$ of Ulva sulphate was dissimilated to sulphide. The effect of the inhibitor, sodium molybdate (Mo), which greatly decreased sulphide concentration and increased sulphate output from the vessels, further demonstrated the high level of activity of sulphate-reducing bacteria in the presence of Ulva. The formation of low levels of sulphide, either in the basal medium, or in Mo-supplemented vessels originated most probably from microbial degradation of the sulphur amino acids, cysteine and methionine in which sulphur exists in its most reduced state. In the rumen, cysteine is known to be degraded into $\mathrm{NH}_{3}$, pyruvate and $\mathrm{H}_{2} \mathrm{~S}$ in the presence of sulfhydrase and feeding methionine to sheep increased the rumen sulphide pool (Doyle and Moir, 1979). We had first expected that supplementation of Ulva with fermentable carbohydrates such as resistant starch would reduce sulphide concentrations by decreasing the $\mathrm{pH}$ and/or by stimulating assimilatory sulphate reduction in relation to the increase in biomass synthesis. Our results did not support this prediction. First, probably because of the high concentration of ammonia, the $\mathrm{pH}$ did not decrease below 6.7 and dissimilatory sulphate reduction was shown to be reduced only below pH 6.5 (Gibson et al, 1990). Further, the rise in biomass synthesis did not support high levels of sulphate incorporation. If we assume that the value of $\mathrm{S} / \mathrm{N}$ ratio in the colonic flora is similar to that reported for rumen microorganisms $(\mathrm{S} / \mathrm{N}=0.06)$ (Durand and Komisarczuk, 1988), we can approximate an increase of $\mathrm{S}$ incorporation into biomass of $0.2-0.4 \mathrm{mmol}$, corresponding to the $200 \mathrm{mg}$ protein- $\mathrm{N}$ induced by resistant starch. This value is negligible compared to the observed sulphide concentrations.

Our results showing that sulphide production from ulvan was negligible confirm the recent observations of Michel et al (1995). These authors concluded that resistance to desulphation appeared to be the limiting factor in ulvan sulphate metabolism by SRB. However, our particular ulvan preparation contained some free sulphate (about 30\%) (Lahaye, personal communication) which was recovered in the culture effluents in the presence as well as in absence of Mo. This would indicate an 
inhibitory effect of ulvan itself on dissimilatory sulphate reduction.

In our studies, inhibition of sulphide reduction by Mo resulted in release of formate and hydrogen. Gibson et al (1988a) also observed that inhibition of SRB by Mo resulted in accumulation of hydrogen in large quantities. In our experiments, however, the production of hydrogen and formate were greater in the presence of resistant starch than with Ulva alone, or when supplemented with algal xylan, despite similar levels of sulphide production in the absence of Mo. This indicates that electron donors for sulphate reduction varied depending on the nature of the polysaccharides being fermented. Low molecular weight organic acids such as lactate, propionate or acetate can be used as electron donors in addition to $\mathrm{H}_{2}$ and formate (Gibson, 1990). Sodium molybdate was not entirely specific against sulphate reduction. Although it did not apparently decrease the total number of anaerobes, it always reduced, whatever the treatment, production of SCFA. This reduction was most apparent with resistant starch $(-18 \%)$. In this case, inhibition of acetate production might have been the consequence of hydrogen accumulation, which is known to inhibit regeneration of reduced electron carriers involved in the oxidation of pyruvate to $\mathrm{CO}_{2}$ and acetyl-CoA in a number of bacterial species. This explanation is not valid, however, for the basal medium, or for Ulva, where $\mathrm{H}_{2}$ production was very low. Our results of ${ }^{13} \mathrm{CO}_{2}$ incorporation into acetate also clearly demonstrate an inhibitory effect of Mo on reductive acetogenesis. Molybdate being a competitive inhibitor, should be added at the equivalent level of ambient sulphate dissolved in the system. A level of $20 \mathrm{mM}$ molybdate is routinely employed in human faecal incubations (Gibson et al, 1988a; Strocchi et al, 1993) without notable inhibitory effects. It is possible that some microbial strains are more susceptible to Mo in continuous rather than in batch cultures. Some inhibitory effects of $20 \mathrm{mM}$ Mo on methane production have been recorded (Oremland and Capone, 1988). Mo is known to form molybdosulphide complexes which can bind available sulphide ions and cause a deficiency in sulphur availability.

The number of sulphate-reducing bacteria (SRB) was relatively high and similar in both original faeces, though donor $\mathrm{B}$ was moderately methanogenic and harboured a significant number of methanogens in her faeces. This absence of a clear-cut inverse relationship between faecal SRB and methanogens is in agreement with the recent results of Doré et al (1995a). However, after adaptation to Ulva in the fermenters inoculated with the flora from donor $B$, the number of methanogens decreased and only trace amounts of $\mathrm{CH}_{4}$ were produced. This inhibition of methanogenesis was, most probably, related to the high sulphate content of Ulva which led to competitive exclusion of methanogens by SRB, as previously observed by Gibson et al (1988a). Here, this exclusion was probably facilitated by the fact that the inoculum was provided by a low $\mathrm{CH}_{4}$ excretor and harboured a moderate number of methanogens. Contrary to methanogenesis, neither the concentration of acetogens nor the reductive acetogenic activity were affected by the adaptation to Ulva. Pure cultures of acetogenic bacteria from the human colon have been shown recently to be extremely versatile with regard to their substrate utilization patterns (Bernalier et al, 1996b), which could facilitate their growth in the presence of active sulphate reducers. The addition of sulphate at a level of $7 \mathrm{mM}$ which is what could be expected in the colon of human subjects consuming about $15 \mathrm{~g}$ dry Ulva, counteracted reductive acetogenesis in one experiment out of two, demonstrating that SRB present in some individual inocula can compete with acetogenic bacteria for $\mathrm{H}_{2}$. This is consistent with previous observations showing fluctuating responses to sulphate addition (Bernalier et al, 1996a). 
In conclusion, we confirmed that Ulva, and particularly its soluble polymer, ulvan, are to a large extent resistant to fermentation, and we have shown that adaptation of the microbiota occurs to a very limited degree. Our results also clearly demonstrate that Ulva, though producing low amounts of SCFA, stimulates sulphide formation by methanogenic and non-methanogenic microfloras, owing to its high free-sulphate content. Its supplementation with more fermentable polysaccharides, though probably beneficial for the host by decreasing ammonia, should not significantly reduce sulphide production. Therefore, it can be postulated that unless crude Ulva is previously processed in order to remove its free sulphate, its regular consumption at a level of 15 or $20 \mathrm{~g}$ of dry product daily could support high activities of sulphate reducing bacteria in the colon, which might interact with other microbial pathways of $\mathrm{H}_{2}$ disposal and be detrimental to the health of the host.

\section{ACKNOWLEDGMENTS}

Part of this work was supported by the EC contract AIR 1 CT 92 518. The authors thank G Macfarlane and C Michel for their helpful advice during this study.

\section{REFERENCES}

Bernalier A, Lelait M, Rochet V, Grivet JP, Gibson GR, Durand M (1996a) Acetogenesis from $\mathrm{H}_{2}$ and $\mathrm{CO}_{2}$ by methane- and non-methane-producing human colonic bacterial communities. FEMS Microbiol Ecol 19, 193-202

Bernalier A, Rochet V, Leclerc M, Doré J, Pochart P (1996b) Diversity of $\mathrm{H}_{2} / \mathrm{CO}_{2}$-utilizing acetogenic bacteria from feces of non-methane-producing humans. Curr Microbiol 32, 1-17

Bo Sörbo (1987) Sulfate: turbidimetric and nephelometric methods. Meth Enzymol 143, 3-6

Bobin-Dubigeon C (1996) Caractérisation chimique, physico-chimique et fermentaire de produits alimentaires à base d'algues. Thèse de Doctorat, Université de Nantes, France
Bobin-Dubigeon C, Lahaye M, Barry JL (1996) Human colonic bacterial degradability of dietary fibres from sea-lettuce (Ulva sp). J Sci Food Agric 73, 149-159

Brunsgaard G, Bach Knudsen KE, Eggum BO (1995) The influence of the period of adaptation on the digestibility of diets containing different types of indigestible polysaccharides in rats. Br J Nutr 74, 833-848

Christl SU, Gibson GR, Cummings JH (1992) Role of dietary sulphate in the regulation of methanogenesis in the human large intestine. Gut 33, 1234-1238

Cline JD (1969) Spectrophotometric determination of hydrogen sulfide in natural waters. Limnol Oceanogr 14, 454-458

Cummings JH (1984) Microbial digestion of complex carbohydrates in man. Proc Nutr Soc 43, 35-44

Cummings JH (1995) Short chain fatty acids. In: Human Colonic Bacteria. Role in Nutrition, Physiology and Pathology (GR Gibson, GT Macfarlanne, eds), CRC Press, Boca Raton, USA, 101130

Czerkawski JW, Breckenridge G (1977) Design and development of a long-term rumen simulation technique (Rusitec). Br J Nutr 38, 371-384

Daly J, Tomlin J, Read NW (1993) The effect of feeding xanthan gum on colonic function in man: correlation with in vitro determinants of bacterial breakdown. BrJ Nutr 69, 897-902

De Graeve KG, Grivet JP, Durand M, Beaumatin P, Cordelet C, Hannequart G, Demeyer D (1994) Competition between reductive acetogenesis and methanogenesis in the pig large intestinal flora. $J$ Appl Bacteriol 76, 55-61

Doré J, Pochart P, Bernalier A, Goderel I, Morvan B, Rambaud JC (1995a) Enumeration of $\mathrm{H}_{2}$-utilizing methanogenic archaea, acetogenic and sulfatereducing bacteria from human faeces. FEMS Microbiol Ecol 17, 279-284

Doré J, Durand M, D'Agay-Abensour L, Pochart P, Flourié B, Bernalier A, Champ M, Rambaud JC (1995b) In vivo and in vitro fermentation of resistant starch and lactulose by human colonic microflora. Reprod Nutr Dev 35, 590-591

Doyle PT, Moir RJ (1979) Sulfur and methionine metabolism in sheep. II. Quantitative estimates of sulfur metabolism in the sheep's stomach. Aust $J$ Biol Sci 32, 65-76

Durand M, Komsarczuk S (1988) Influence of major minerals on rumen microbiota. $J$ Nutr 118,249 260

Durand M, Bernalier A, Doré J (1995) Hydrogen metabolism in the colon. In: Dietary Fibre and Fermentation in the Colon, COST92 Workshop, Espoo Finland

Edwards CA (1995) Dietary fibre, fermentation and the colon. In: Dietary Fibre. Mechanisms of Action 
in Human Physiology and Metabolism (C Cherbut, JL Barry, D Lairon, M Durand, eds), John Libbey Eurotext, Paris, France, 51-60

Faisant N, Champ M, Colonna P, Buléon A, Molis C, Langkilde AM, Schweizer T, Flourié B, Galmiche JP (1993) Structural features of resistant starch at the end of the human small intestine. Eur J Clin Nutr 47, 285-296

Florin T, Neale G, Gibson GR, Christl SU, Cummings JH (1991) Metabolism of dietary sulphate: absorption and excretion in humans. Gut 32, 766-773

Gibson GR (1990) Physiology and ecology of the sulphate-reducing bacteria. J Appl Bacteriol 69, 769797

Gibson GR, Cummings JH, Macfarlane GT (1988a) Competition for hydrogen between sulphate-reducing bacteria and methanogenic bacteria from the human large intestine. J Appl Bacteriol 65, 241247

Gibson GR, Cummings JH, Macfarlane GT (1988b) Use of a three-stage continuous culture system to study the effect of mucin on dissimilatory sulfate reduction and methanogenesis by mixed populations of human gut bacteria. Appl Environ Microbiol $54,2750-2755$

Gibson GR, Cummings JH, Macfarlane GT, Allison C, Segal I, Vorster HH, Walker ARP (1990) Alternative pathways for hydrogen disposal during fermentation in the human colon. Gut 31, 679-683

Gibson GR, Cummings JH, Macfarlane GT (1991) Growth and activities of sulphate-reducing bacteria in gut contents of healthy subjects and patients with ulcerative colitis. FEMS Microbiol Ecol 86, 103112

Lahaye M (1991) Marine algae as sources of fibres: determination of soluble and insoluble dietary fibre contents in some sea vegetables. J Sci Food Agric $54,587-594$

Lahaye M, Axelos M (1993) Gelling properties of water-soluble polysaccharides from proliferating marine green seaweeds (Ulva spp). Carbohydr Polym 22, 261-265

Lahaye M, Michel C, Barry JL (1993) Chemical, physicochemical and in-vitro fermentation characteristics of dietary fibres from Palmaria palmata (L) Kuntze, Food Chem 47, 29-36

Macfarlane GT, Cummings JH (1991) The colonic flora, fermentation, and large bowel digestive function. In: The Large Intestine: Physiology, Pathophysiology and Disease (SF Phillips, JH Pemberton, RG Shorter, eds), Raven Press Ltd, New York, USA, 51-92

Macfarlane GT, Hay S, Macfarlane S, Gibson GR (1990) Effect of different carbohydrates on growth, polysaccharidase and glycosidase production by Bacteroides ovatus, in batch and continuous culture. J Appl Bacteriol 68, 179-187
Michel C, Macfarlane GT (1996) Digestive fates of soluble polysaccharides from marine macroalagae: involvement of the colonic microflora and physiological consequences for the host. $J$ Appl Bacteriol $80,349-369$

Michel C, Willis CL, Gibson GR (1995) Fermentation of soluble sulphated algal, polysaccharides by human colonic bacteria ecological, significance in relation to hydrogenotrophic species. Soc Gen Microbiol Abs Booklet, P30

Michel C, Lahaye M, Bonnet C, Mabeau S, Barry JL (1996) In vitro fermentation by human faecal bacterial of total and purified dietary fibres from brown seaweeds. Br J Nutr 75, 263-280

Monsma DJ, Marlett JA (1996) Fermentation of carbohydrate in rat ileal excreta is enhanced with cecal inocula compared with fecal inocula. J Nutr 126 , 554-563

Oremland RS, Capone DG (1988) Use of specific inhibitors in biogeochemistry and microbial ecology. Adv Microb Ecol 10, 285-393

Ray B, Lahaye M (1995) Cell-wall polysaccharides from the marine green algae Ulva rigida (Ulvales, Chlorophyta). Extraction and chemical composition. Carbohydr Res 274, 251-261

Richardson AJ, Calder AG, Stewart CS, Smith A (1989) Simultaneous determination of volatile and non-volatile acidic fermentation products of anaerobes by capillary gas chromatography. Lett Appl Microbiol 9, 5-8

Roediger WEW, Duncan A, Kapaniris O, Millard S (1993) Reducing sulfur compounds of the colon impair colonocyte nutrition: implications for ulcerative colitis. Gastroenterology 104, 802-809

Salyers AA (1985) Breakdown of polysaccharides by human intestinal bacteria. $J$ Environ Pathol Toxicol Oncol 5, 211-231

Strocchi A, Ellis CJ, Levitt MD (1993) Use of metabolic inhibitors to study $\mathrm{H}_{2}$ consumption by human feces: evidence for a pathway other than metanogenesis and sulfate reduction. J Lab Clin Med 121, 320-327

Tulung B, Rémésy C, Demigné C (1987) Specific effects of guar gum of gum arabic on adaptation of cecal digestion to high fiber diets in the rat. $J$ Nutr 117, 1556-1561

Walter DJ, Eastwood MA, Brydon WG, Elton RA (1986) An experimental design to study colonic fibre fermentation in the rat: the duration of feeding. Br J Nutr 55, 465-479

Wyatt GM, Bayliss CE, Holcroft JD (1986) A change in human faecal flora in response to inclusion of gum arabic in the diet. BrJ Nutr 55, 261-266 